Language Teaching Research Quarterly

$\overbrace{}^{+}$

LTRQ

\section{Language Teaching Research Quarterly}

2018, Vol. 7, 25-56

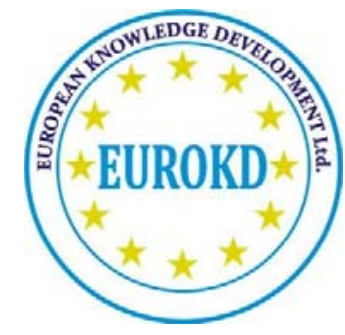

\title{
Background Reading Text Technique to Promote Learners' Argumentative Compositions: The Case of Second Year LMD Students of English Groups 9 and 10
}

\author{
Lyna Sabbah, Loubna Sabbah \\ University of Abderrahmane-Mira, Bejaia (Algeria)
}

Received 23 December 2017 Accepted 12 June 2018

\begin{abstract}
The present inquiry is conducted under the title "Background Reading Text Technique to Promote Learners' Argumentative Compositions". Its aim is to establish the relevance of teaching writing skills through reading assignments to second year LMD students of English, at the University of Abderrahmane-Mira, Bejaia (Algeria). It is an attempt to explore the nature of the contribution of the Background Reading Text Technique to learners' competence in argumentative compositions. In view of that, this investigation concerns itself with the issue of how to brush up writing skills using the Background Reading Text Technique. As a solution for the aforementioned problem, we hypothesize that "If the learners compose by means of analysing previously reading assignments, they may be able to plan more effectively and write better argumentative essays". To tackle this problem, we have adopted an experimental method using an analytic, quantitative approach. The anticipated findings of the experimental manipulation indicate that the Background Reading Text Technique is a significant contributory strategy during written expression classes to develop learners' argumentative compositions, particularly at the level of vocabulary use and organisational skills.
\end{abstract}

Keywords: Background Reading Text Technique- Promote - Argumentative CompositionsRelevance- Writing Skills- Analysing- Reading Assignments- Contribution

The realm of teaching and learning has been a fertile ground for applied linguists in their attempts to resolve real-world language-based problems. Since about 50 years, applied linguistics has immersed in researches and experimentations to brush-up writing skills, for either first language 
$\left(\mathrm{L}_{1}\right)$ or second language $\left(\mathrm{L}_{2}\right)$ learners (Grabe \& Kaplan, 1996, p.1). Indeed, it is a commonplace these prevailing years that the poor composition skills of students have become a serious issue among the teachers and the press (Uusen, 2006, p.5). Composing stylish texts is especially problematic for non-native speakers as they need to have a command of a new language. They must balance various criteria like content, organisation, audience, vocabulary, punctuation, spelling, and mechanics such as capitalisation (Abu Rass, 2006, p.5). This scope then is global which explains the excessive studies and projects dealing with such a topic. Certainly, these inquiries have been based upon a series of broad, sound insights which denote the corner-stone before conducting any investigation. For this reason, the current paper opens with reviews of the existing literature related to some issues paramount to our research project. Then, it traces in detail the development of a particular subset of linguistic forms of second year students of English by means of the Background Reading Text Technique during the experimental manipulation.

\section{I- A Historical Sketch}

\section{I.1. The Essence of Writing}

I.1.1 Definition. It is an ubiquitous fact that providing a sheer, unique definition of the writing skill is unfeasible. This has given a constant, fresh impetus for new perceptions and concepts to come up. Scholars have established a myriad of wording that mirror the divergent views and approaches they hold about the essence of writing. That is to say, to think of writing as a product, a process, a skill, or a combination of the three. To set the stage, we will shed light on several definitions that contend our claims. In 2006, Uusen has provided a summary reporting that writing is:

... producing visual symbols for the reader;... a process with multiple features, where meanings and messages are created for the reader to interpret; ... expressing ideas using letters, words, art or media, something that can happen only if mental operations (processes) are mobilized to express ideas; writing is a skill that integrates knowledge and skill, it is an action which contains language, thoughts, experience, feelings, emotions, mechanical actions and different strategies; etc. (p.7)

Admittedly, due to the consensus that writing definition is inextricably correlated with "the type of purpose, style, and audience" (Lina, 2007, p.9), all the previous attempts to examine the nature of writing can be correct. However, we believe that a useful way to penetrate the intricacies of this concept is by conferring on a simple definition, then, elaborating it into a more complex one. In this vein, we agree on that writing is the act of forming graphic symbols, letters or combination of letters, which relate to the sounds we enunciate when we speak. That means making marks on a flat surface of some kind known as Spelling (Byrne, 1988, p.1). Writing becomes a more complicated process when it entails the construction of words and sentences accepted by the language system (first or second language). In this case, we name the activity Writing Practice (Raims, 1983). Granted, the language acquirers do not write just isolated, unrelated sentences. They also produce a sequence of arranged sentences according to the graphic conventions of the language, with a careful scrutiny of the vocabulary and the linguistic structures to be employed, and an intention of expressing themselves in an elegant fashion. The result is a 
coherent whole, thus, a text. At this stage, the writing skill reaches its most advanced level. Hence, it will be recognized as Composition (Ibid). Since our project is limited to the composition stage, we will use the terms writing and composition interchangeably.

In short, the more the language learner advances in his level and writing abilities, the more defining the writing skill becomes a tedious task. The next sub-title will bring up in a clear way such orthodoxy and its factors.

I.I.2. Components. Throughout learners' progressive processes from the spelling stage to the composition, various ongoing capabilities foster and broach. The development of thoughts representation in a well-structured form embodies distinct elements and conditions whereby effective compositions are produced. This means that writing is more complex than it seems at first; it often appears to be the hardest of the skills, for both native and non-native speakers of a language (Byrne, 1988; Kroll, 1990; Weigle, 2002). The several sub-skills are subsumed under the writing skill are numerous. The list is not fixed or unchangeable; nevertheless, it can be modified or enriched. It implies:

1-The use of the orthography correctly, including the script, spelling, and punctuation conventions. 2-The use of forms that express the right tense, case, or gender.

3-The application of syntactic rules.

4-The choice of the style appropriate to the genre and audience.

5 -The clearness in making the main sentence constituents.

6-The accurate establishment of the main ideas distinct from supporting ideas or information.

7-The respect of coherence.

8-The adequate selection of the content to be transmitted. (SIL International, 1999, p. 1)

In fact, the above sub-skills overlap the two sides of writing: the contents and the form. They represent the linguistic and the rhetoric resources upon which the language learner draws to construct a cohesive, coherent text. The following figure illustrates the prerequisites of each.

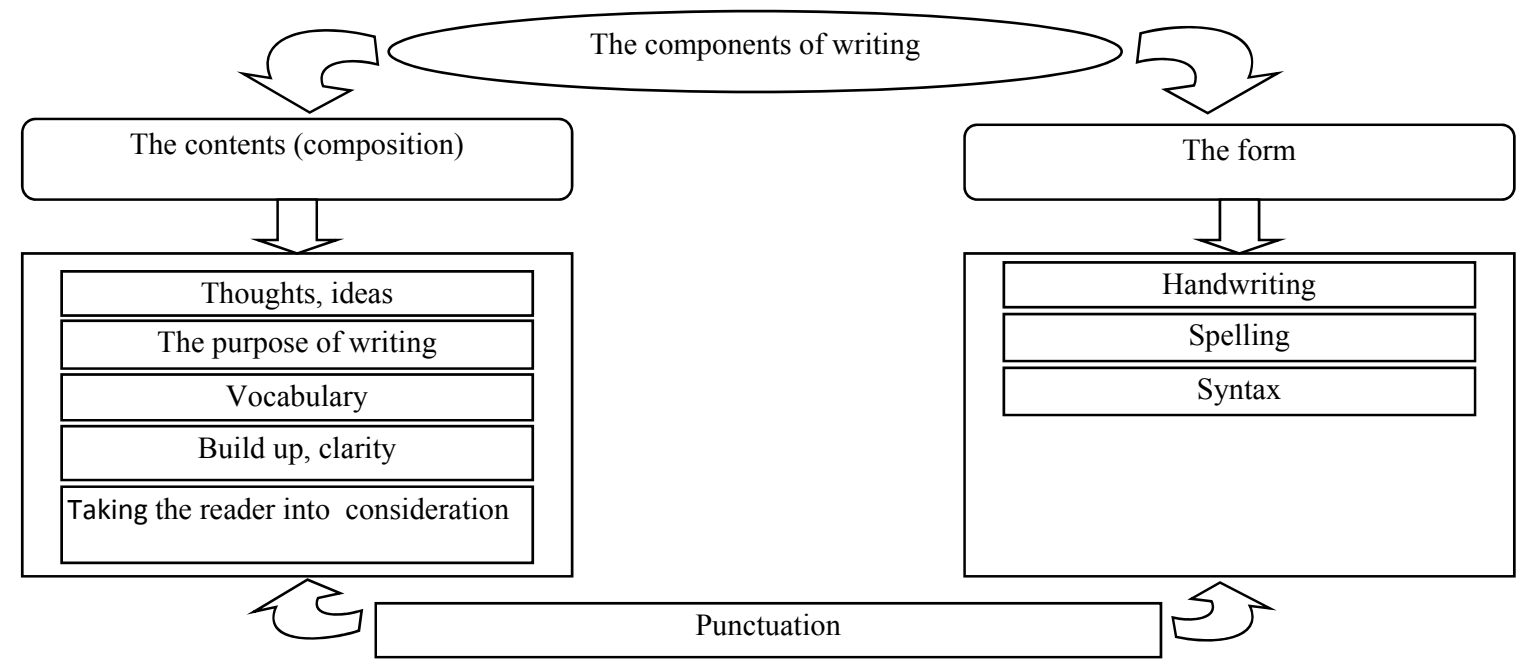

Figure 1. The Components of Writing (This diagram is a development of a graph designed by Uusen, 2006)

As the graph demonstrates, punctuation is a key part of both the contents and the form. It is 
connected with syntax (grammar) and with semantics (meaning) (Allan \& Miller, 2001; Riley \& Reidy, 2000).

Overall, the previous discussion conveys an awareness of the writing intricacies and resources. Besides, the number and the categorisation of the writing sub-skills suggest the difficulty of text composing. The reasons behind such a problem are particulised under the coming title.

I.1.3. Writing aspects. Writing is a solitary activity. It is particularly a matter of internal cognitive abilities and sound knowledge of the code (the language system). Yet, the socio-cultural milieu is qualified as the primary external source for people to develop their language competence and brush up their performance (skills). As a result, any try at establishing writing programmes should overlap the three chief aspects of the writing skill: the cognitive, the social, and the cultural.

I.1.3.1. The cognitive aspect of writing. There have been several studies which have drawn attention to the mental activities and decision making processes of the writer while carrying out a writing task (Perl, 1979; Flower \& Hayes, 1980; Sommer, 1980; Zamel, 1983; Raimes, 1985). The investigations have concentrated on capturing the differences between expert and novice writers. Henceforth, various cognitive models of the writing process have been generated. They have addressed questions like: what are the cognitive processes involved in writing? What sources of knowledge does the writer draw upon in writing? What other factors influence the writing process? (Weigle, 2002, pp. 22-23).

One reflective model is provided by Hayes (1996) (Figure2). Hayes perceives the writing process as a consolidation of two parts: the task environment and the individual. On the one hand, the task environment includes the social environment and the physical environment. The former is concerned with the audience (real or imagined) to whom the writer composes, and the collaborators (e.g. teacher, peers) who facilitate the composing process to the learner. The latter consists of the text produced so far and the composing medium, that is, the means used to write (e.g. handwriting, word processors).

The individual, on the other hand, is the central focus in Hayes' Model. It covers four main sub-parts, each with its own components. First of all is the working memory. It comprises three components: the phonological memory, which stores auditory/verbal information (speech); the visual, spatial sketchpad, whose function is to store visually or specially coded information (e.g. written words or graphs); the semantic memory that serves to store conceptual information. Second, the critical role of affective factors is highlighted in the Hayes' Model. He confirms that these variables determine the way the learner processes the writing task, and the effort he will make to achieve success.

The third sub-part represents the cognitive processes. It involves: the text interpretation including listening, reading, and scanning graphics processes to transform the linguistic, graphic input into mental representations; the reflection process to create new schemas from the preexisting ones; the text production process by which new linguistic (written or spoken) or graphic output is generated from internal presentation. These three processes intervene when drafting as well as revising a piece of writing. The last individual sub-part is the long term memory. It comprises task schemas, topic knowledge, and audience knowledge, linguistic knowledge, and 
genre knowledge. Hayes conceptualises the task schemas as "packages of information stored in long-term memory that specify how to carry out a particular task" (p.24). The topic knowledge refers to the writer's schema about the subject matter he will treat. Knowledge of the audience implies consideration of the social and cultural issues which will be discussed later. The linguistic knowledge encompasses knowledge about the language resources which are essential to produce a written discourse. Lastly, the genre knowledge reflects knowledge about the appropriate forms that writing takes in a particular situation, for a specific purpose, and according to socio-cultural norms (Swales, 1990).

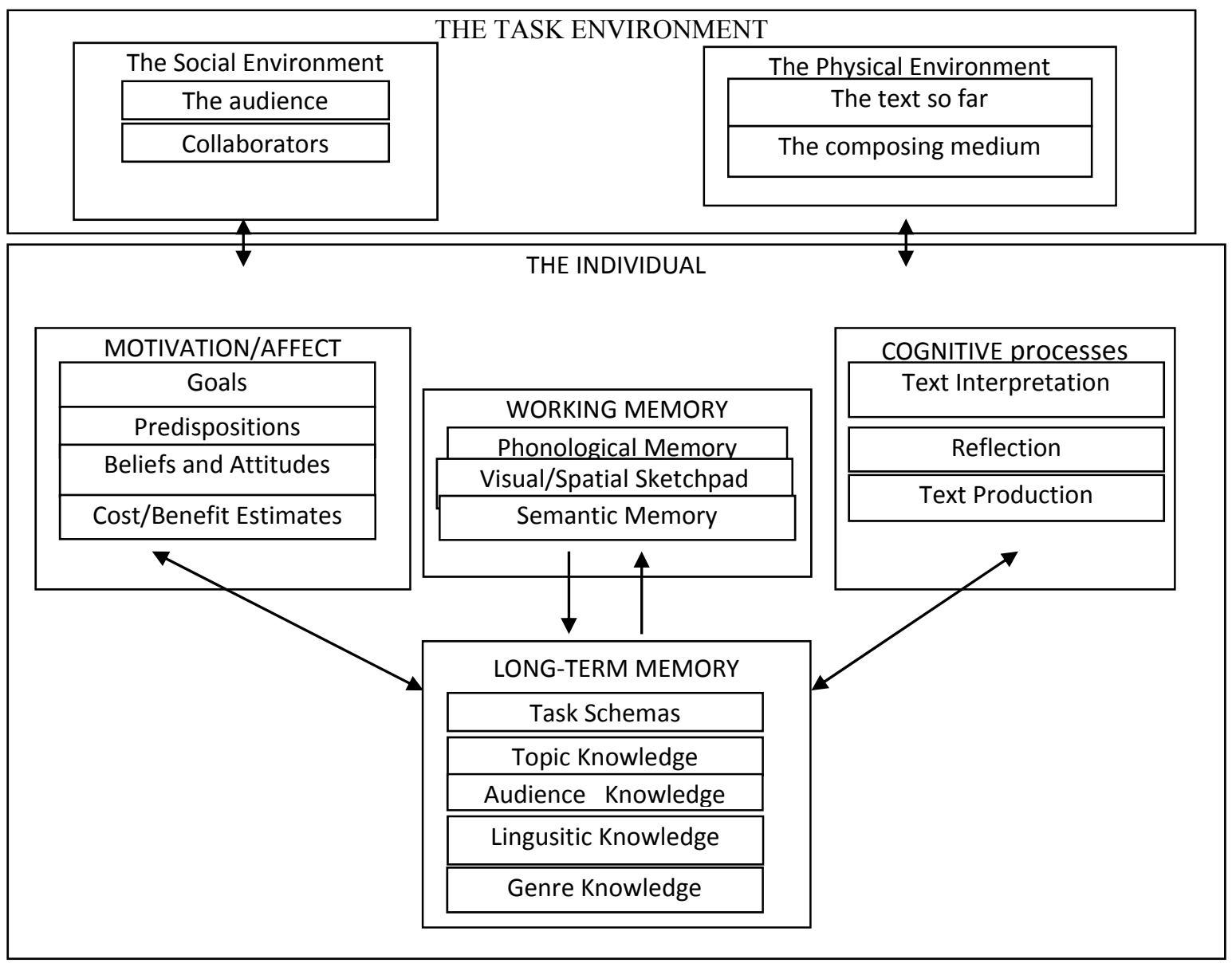

Figure 2. The Hayes' Model (1996)

Absolutely, the Hayes'Model is immensely influential in many respects. But when speaking about a second language context, two main short-comings emerge. The first is that the model does not supply a specific definition of the situational variables included in writing. The second is that the components of the linguistic knowledge do not cover all the pre-requisites of a text composition (Weigle, 2002, p. 28). In order to bridge these gaps, we provide another prevalent model. It is that of Grabe and Kaplan (1996) which is shown in table (1) below.

Table 1. Taxonomy of language knowledge (Adapted from Grabe and Kaplan, 1996, pp. 220WwW.EUROKD.COM Doi: 
221).

I- Linguistic knowledge

A. Knowledge of the written code

1.Orthography

2. Spelling

3.Punctuation

4.Formatting conventions (margins, paragraphing, spacing, etc.)

B. Knowledge of phonology and morphology

1. Sound/letter correspondences

2. Syllables (onset, rhyme/ rhythm. coda)

3. Morpheme structure (word-part knowledge)

C. Vocabulary

1. Interpersonal words and phrases

2. Academic and pedagogical words and phrases

3. Formal and technical words and phrases

4. Topic-specific words and phrases

5. Non-literal and metaphoric language

D. Syntactic/structural knowledge

1. Basic syntactic patterns

2. Preferred formal writing structures (appropriate style)

3. Tropes and figures of expression

4. Metaphors/similes

E. Awareness of differences across languages

F. Awareness of relative proficiency in different languages and registers

\section{II- Discourse knowledge}

A. Knowledge of intrasentential and intersentential marking devices (cohesion, syntactic parallelism)

B. Knowledge of informational structuring (topic/comment, given/new, theme/rhyme, adjacency pairs)

C. Knowledge of semantic relations across clauses

D. Knowledge of recognizing main topics

E. Knowledge of genre structure and genre constraints

F. Knowledge of organizing schemes (top-level discourse structure)

G. Knowledge of inferencing (bridging, elaborating)

H. Knowledge of differences in features of discourse structuring across languages and cultures

I. Awareness of different proficiency levels of discourse skills in different languages

\section{Sociolinguistic knowledge}

A. Functional uses of written language

B. Application and interpretable violation of Gricean maxims (Grice, 1975)

C. Register and situational parameters

1. Age of writer

2. $\quad$ Language used by writer $(1.1,1.2 \ldots)$

3. Proficiency in language used

4. Audience considerations

5. Relative status of interactants (power politeness)

6. Degree of formality (deference/solidarity)

7. Degree of distance (detachment/involvement)

8. Topic of interaction 
9. Means of writing (pen/pencil, computer, dictation, shorthand)

10. Means of transmission (single page/book/read aloud/printed)

D. Awareness of sociolinguistic differences across languages and cultures

E. Self-awareness of roles of register and situational parameters

To put it briefly, the formerly mentioned models are instances of the modern approaches to examine the cognitive aspects of writing. The approaches that view the writing process as an interactive amalgam of variables rather than pure cognitive processes.

I.I.3.2. The social aspects of writing. As we have earlier noted, a written text is by no means a complex product of the individual, the society, and the culture. Writing is an act which is associated with a context, which fulfils a particular purpose, and which takes a given form adequate for the target audience (Hamp-Lyons \& Kroll, 1997, p. 8). Sharing the same view, the eminent proponent of the social nature of writing Hayes (1996) contends:

[Writing] is also social because it is a social artifact and is carried out in a social setting. What we write, how we write, and who we write to is shaped by social convention and by our history of social interaction... (Hayes, 1996, p. 5).

Consequently, learners, specifically non-native speakers of a language, should he introduced to the distinct social conventions that shape the written discourse of the target language. That means taking into account the content, the style, the features of discourse structuring, the genre, and the audience.

I.I.3.3. The cultural aspects of writing. The effect of culture on individuals' writings has been raised in many inquiries (Kaplan, 1966; Grabe \& Kaplan, 1989, 1996; Leki, 1992; Brown, 1994). In this light, Grabe and Kaplan (1996) assert that variation in writing is not a reflection of inherent differences in thought; however, it reflects "cultural preferences which make greater use of certain options among the linguistic possibilities" (p. 184). To illustrate, Arabic prose is characterised by an excessive use of coordination and parallelism. On the contrary, attention is paid to the subordination and hierarchical organisation in English prose (Yorkey, 1977; Ostler, 1987).

Furthermore, certain languages like English have been described as writer - responsible languages (Hinds, 1987). This implies that it is the writer's responsibility to establish explicit connections between propositions and ideas in the text. The reader-responsible languages, whereas, put the onus on the reader to infer the writer's message, wherein many aspects have been left implicit. As a logical consequence, learners from one of the preceding cultural backgrounds or others will face real problems to write in a different cultural context. Hence, second language teachers should be aware of these issues and should increase the learners' awareness too.

To put it in a nutshell, writing is a cognitive, social, and cultural human activity. It is an expression of mental abilities and skills of socio-cultural norms, conventions, and preferences. Such a conclusion has been the fruit of long, hard endeavour, of numerous researchers, opting to flurries of approaches. In the light of this, the last title within this section will introduce the developmental pathway of composition instruction in second/foreign language contexts. (In what follows the words second language and foreign language are used interchangeably). 


\section{2. The Development of Second Language Composition Approaches}

Before proceeding to the discussion, we would like to explain that because the main concern of this study is the composing skills in classroom essays, the focus here will be on composition approaches. Nonetheless, they are reflections of the writing approaches in general.

The threshold of (SL) composition approaches is dated since about 1945. It represents the beginning of the modern era of second language teaching in the United States (Silvia; cited in Kroll, 1990, p. 11). To trace the historical development of these directions is to speak about a merry-go-round of orientations to $\left(\mathrm{L}_{2}\right)$ writing: the Controlled Composition, the Current Traditional Rhetoric, the Process Approach, and the English for Academic Purposes.

I.2.1. The controlled composition approach. The controlled composition or guided composition is derived from Charles Fries' (1945) Oral Approach, the forerunner of the audio-lingual method of second language teaching. The tenet of this approach encompasses the view of language as speech (structural linguistics) and learning as a habit formation (behaviouristic psychology). Hence, writing is regarded as a secondary concern. Its function is to maintain oral habits (listening, speaking, and reading) since it is "the handmaid of the other skills" (Rivers, 1968, p.241). Writing is the practice of clothing abstract ideas by means of linguistic entities (words, clauses, sentences), arranged according to the system rules.

From this perspective, learners' compositions are viewed as langue (Hyland, 2002, p. 7). Their task is to imitate, manipulate, and demonstrate knowledge of language forms - punctuation, grammar, vocabulary, and spelling - while generating texts. The teacher functions as an editor (Silvia, cited in Kroll, 1990, p. 13). He is mainly concerned with the accuracy of linguistic structures and features rather than the quality of ideas and expressions.

I.2. 2. The current traditional rhetoric approach. By the mid sixties, opposing views have emerged as a riposte to the limitations of the controlled composition approach. Subsequently, the current traditional rhetoric paradigm has been brought to the surface. It has been founded on the principles of the Current Traditional Paradigm and Kaplan's (1967) theory of Contrastive Rhetoric. In relation with the former, Richard Young (1978) points out that the emphasis is on the composed product rather than on the composing process. Additionally, the analysis of discourse should include the segmentation of the text into words, sentences, and paragraphs (p.31). For the latter, Kaplan suggests that ESL writers "employ a rhetoric and a sequence of thought which violate the expectations of the native reader" (p. 4). By rhetoric, he means the method of organising syntactic units into large patterns.

The focus in the Current Traditional Rhetoric Model, then, is the paragraph and the essay development. On one side, a careful examination of the paragraph elements (topic sentence, support sentences, concluding sentences, and transitions) as well as its functions (illustration, exemplification, comparison, contrast, and so on) is necessary. On the other side, essays are just extensions of the paragraph principles to larger discourse forms. Accordingly, writing is a result of arranging, connecting sentences and paragraphs into prescribed patterns.

In this orientation, learners are inclined to complete pre-existing models. The content is either provided or generated by the learner himself. The teacher is seen as a member of the community 
of educated native speakers. His task is to evaluate the discourse structures (sentences, paragraphs, sections, etc) in learners' compositions.

I.2.3. The process approach. Depicted as a paradigm shift (Hairston, 1982), the Process Approach has grown up to overlap the two previous models with novel insights. The inappropriate principles of the guided composition model, the linearity and prescriptivism of the current traditional rhetoric perspective have given birth to the process approach. Its roots originate from Taylor's (1981) and Zamel's (1982) views, presuming that advanced (ESL) learners make use of strategies and skills similar to those of native speakers of English. In such orientation, composing embodies a non-linear process, with an intention of exploring and creating ideas, in an attempt to approximate meaning (Zamel, 1983a, p.165). In an alternative concise definition, Raimes (1983a) asserts that "composing means expressing ideas, conveying meaning. Composing means thinking" (p. 261).

As a result, learners are active agents in the discovery and expression of meaning. They compose in a healthy learning environment, with plenty of time and minimal guidance. The instructor serves as a facilitator; he aids learners to foster writing strategies before, during, and after the composing process. Unlike the other approaches, the priority in assessing learners' texts is devoted to the content, the ideas, and the meaning. Less attention is given to the form.

I.2.4. The English for academic purposes approach. The increasing criticisms against the Process-Oriented Approach have induced the proponents of English for Academic Purposes to introduce their model. The Process Approach has been deplored for two prime reasons. First of all, as Reid (1984 a, b) has argued, it neglects the variations in the writing process, which result from differences in individuals, writing tasks, development of schemata for academic discourse, and so on. The second major weakness is that the conditions under which learners compose in the process model slightly resemble to the real conditions of (SL) writing classrooms (Horowitz, 1986 a, p.144). In other words, the contexts created do not reflect the academic contexts. Moreover, he sees that there is an overemphasis on learners' psychological facets, with an ignorance of the sociocultural aspect. Therefore, the English for academic purposes has appeared to bridge these gaps.

The origins of this orientation seem to be the works of Ewer and Latorre (1969), Swales (1971), Selinker and Trimble (1976), and others, wherein descriptions of scientific and technical English are made. The canon of these publications is that teaching written English, say, for biologists is different from English for engineers or technicians. Though its roots go back to the late 1960s and early 1970s, the (EAP) Model is the last approach to come up on the scene of (SL) writing classrooms. An (EAP) perspective comprises a particular category of events, connected by common purposes, which a specific group of learners are engaged in fulfilling (Hyland \& HampLyons, 2002, p.17). Its focal point is the academic discourse genres in addition to the range, the nature of academic writing tasks. Learning to write requires a social involvement in the academic community. To write is to produce a prose that applies the standards of an American academic institution (Silvia; cited in Kroll, 1990, p.17). The learner is pragmatic. His task is to meet the standards and the requirements to reach high academic achievements. The teacher is an elite, well informed reader about the academic discourse. His role is to provide writing tasks of various genres 
and functions. He evaluates the learners' productions according to the criteria established by the academic community.

To conclude, this historical sketch has covered the four prominent approaches to ( $\left.\mathrm{L}_{2}\right)$ composition. In the first place, the controlled composition model which adopts the view of writing as a habit formation. Its focus is the final linguistic product; it is a mirror of the Product Approach in teaching writing. In the second place, the Current Traditional Rhetoric and the English for Academic Purposes represent two broad branches of the Genre Approach. The former approaches writing in terms of arrangement and connection of linguistic segments into larger functional forms. The latter depicts writing as generating discourse genres that meet the academic standards. In the third place, the Process Approach perceives writing as a process which involves thinking, expressing ideas, and communicating meaning. It is the closest point of connection between writing approaches in general and composition models in particular. In essence, all these approaches are valuable attempts to transcend (SL) learners' capabilities and skills in writing.

\section{I.3. Reading and Writing Connections}

I.3.1. Relationship. Traditionally, reading and writing have been thought of as two disconnected skills. The $1970_{\mathrm{s}}$ and $1980_{\mathrm{s}}$, paradoxically, have witnessed the emergence of new insights. Scholars' curiosity has induced a paradigm shift toward examining the nature and the impact of the relationship between reading and writing. The studies have been conducted in many educational disciplines, typically the educational psychology. The scholarship has revealed the fact that the two skills work in synergy (Tierney, 1992).

Subsequently, three interrelated models about the reading - writing relationship have been established. As a point of entry, the Directional Perspective has taken place. It states that a direct instruction of either the reading or the writing skills will lead to improvements in the other. For instance, the studies of Eckholf (1983), Taylor and Beach (1984) have maintained the hypothesis that reading assignments are useful input for the acquisition of writing skills. In a reflective survey, Stotsky (1983) has shown that reading is more effective in promoting writing than grammar exercises and writing practice. Meanwhile, many researchers view the direction of the influence differently. They suggest that writing drills significantly contribute to reading comprehension and retention of information (Stotsky, 1983). Moreover, Belanger (1987) has mentioned inquiries showing that direct instruction in sentence, paragraph, and discourse structure for writing develops the reading proficiency. In fact, this model provides teachers with clues about which skill to be taught first and in which context. Additionally, it assumes that there are shared structural components between reading and writing that can be transferred from one area to another, in a unidirectional way (Kroll, 1990, p. 90).

Next, the reading-writing relationship is seen as Non-Directional. The two skills evolve from one single cognitive process of constructing meaning. They interact and relate to each other since both of them are constructive processes (Shanklin, 1982). In this light, Shanahan (1984) asserts that "if reading and writing involve analogous cognitive structures and processes, it is possible that instruction in one would lead to increased ability in the other" (p. 467). Here, the emphasis is 
firmly placed on that transfer can occur in either directions, that is to say, from writing to reading or vice versa. Such ideas have been contended by the investigations of Hiebert, Englert, and Brennan (1983). They have found that the interactive relationship between reading and writing immensely affects the recognition and production of different text.

Lastly, certain scholars advocate a Bidirectional relationship between reading and writing. It is the most complex model that implies interactive as well as an interdependent link between the two skills. In this vein, Shanahan and Lomax (1986) claim that the reading-writing relationship is a "constellation of interrelated processes that utilize a number of knowledge bases" (p. 116). Hence, the link is based upon a set of relations that might change in nature with development. To illustrate, Shanahan (1984) has demonstrated that the interactivity between reading and writing has been at the level of word recognition and spelling ability for second graders. By grade five, the relations have covered reading comprehension, organizational structure, and vocabulary diversity.

Overall, what should be born in mind is that the central difference between the three orientations occurs at the level of transfer. In a Directional Model, what is transferred from reading to writing or from writing to reading is perceived as a separate system or knowledge base. This latter is acquired in one area and then is transferred to the other. Paradoxically, a Non-Directional Model considers the transfer interactive and derived from one unique underlying system or knowledge base. It is acquired in either domain (reading or writing) then is transferred to the other. The Bidirectional Model is the most complete. It suggests that the relationship between reading and writing is qualitative. This means multiple relations and processes which interact differently at various stages of development. Doubtless, the previous discussion has given some hints about the existence of common and uncommon aspects between both skills. These will be highlighted under the following title.

I.3.2. Similarities and differences. The extensive interdisciplinary research into reading and writing has induced an interest to identify the similarities and the differences that both skills encompass. The spearheads in this realm have been the constructivists (Gregg \& Steinberg, 1980) and the cognitivists (Aulls, 1985; Kucer, 1987). They have foculised on the interaction between the reader /writer and the text. On the one hand, the reader decodes and builds meaning from the text. On the other hand, the writer encodes and builds meaning for the text (Nelson, 1998, p. 279). To begin with, we will sum up the points in common between the reader and the writer processing of a piece of writing. Afterward, we will discuss the differences.

Table 2. The similarities between reading and writing

\begin{tabular}{|c|l|}
\hline The common aspects & \multicolumn{1}{c|}{ The details } \\
\hline $\begin{array}{c}\text { Meaning making } \\
\text { activities }\end{array}$ & $\begin{array}{l}\text {-When people read and write, meaning is continually in a state of becoming. The mind } \\
\text { anticipates, looks back, and forms momentary impressions that change and grow as } \\
\text { meaning develops (Fillmore, 1981; Langer, 1984). }\end{array}$ \\
\hline Composing activities & $\begin{array}{l}\text {-Both reading and writing involve planning, generating, revising, and monitoring } \\
\text { meaning. (Graves \& Hansen, 1983; Smith, 1983). }\end{array}$ \\
\hline & $\begin{array}{l}\text {-The reader is viewed as a writer in that his mind races ahead to anticipate the message, } \\
\text { structure, and presentational style of a piece. Similarly, the writer often tries to place }\end{array}$ \\
\hline
\end{tabular}

WWw.EUROKD.COM Doi: 


\begin{tabular}{|c|l|}
\hline $\begin{array}{c}\text { Interchangeability of } \\
\text { roles }\end{array}$ & $\begin{array}{l}\text { himself in the shoes of his audience in order to check the comprehensibility of his } \\
\text { presentation from the reader's perspective (Flower \& Hayes, 1980; Bereiter \& } \\
\text { Scardamlia, 1982). }\end{array}$ \\
\hline \multirow{3}{*}{ Kinds of knowledge } & $\begin{array}{l}\text {-Readers and writers employ similar kinds of knowledge in the act of making meanings: } \\
\text { knowledge about language, content, genre, conventions, organization and structure, } \\
\text { pragmatics (Aulls, 1985; Flood \& Lapp, 1987). }\end{array}$ \\
\hline
\end{tabular}

Table 3. The Differences between reading and writing

\begin{tabular}{|c|l|}
\hline $\begin{array}{c}\text { The uncommon } \\
\text { aspects }\end{array}$ & \multicolumn{1}{c|}{ The details } \\
\hline $\begin{array}{c}\text { The type of purpose, } \\
\text { activity, strategy. }\end{array}$ & $\begin{array}{l}\text {-The purpose behind interpreting a text is different from that of producing a piece of } \\
\text { writing. The nature of the activities the language reader is engaged in vary from those the } \\
\text { language writer is immersed in. the monitoring behaviours and the specific strategies used } \\
\text { before, during, and after reading and writing are dissimilar (Langer, 1986). }\end{array}$ \\
\hline $\begin{array}{c}\text { The approaches across } \\
\text { ages }\end{array}$ & $\begin{array}{l}\text {-The approaches the language reader makes use of are distinguishable from the } \\
\text { approaches the language writer employs. (Langer, 1986a; Ammon \& Webster, 1994). }\end{array}$ \\
\hline
\end{tabular}

All in all, the correlations between reading and writing processes are deep in nature. They are concerned with the knowledge sources and the steps of building meanings. Yet, the differences are more superficial. They constitute the ways of structuring messages and the strategies used to construct and organize them. These latter are determined by the purpose of each process: reading or writing. At any rate, the earlier points supply keen insights of practical use to incorporate the reading skill into the second language writing classrooms.

\section{I.4. The Implementation of the Background Reading Text Technique in Writing Classrooms}

I.4.1. An overview. The correlation between reading and writing during composition courses has been spearheaded with native English writers. (TESL - EJ, 1994, p.1). During the $1980_{\mathrm{s}}$, the pioneers in this field (Carrell \& Eisterhold, 1983; Shih, 1986; Zamel, 1987) have tried to examine the effect of such connection on (SL) writing proficiency. Known as Content Based Approach (Shih, 1986), Background Reading Text Approach (Campbell, 1990), or Text Centered Approach (Escribano, 1999), the purposes and the methods to integrate reading with writing skills have varied. In this study, we have adopted the Background Reading Text as a label to our technique.

The Background Reading Text is a technique that considers information from reading texts as a raw material to construct learners' compositions. It aims particularly at developing the quotation, paraphrasing, and summarizing skills (Kroll, 1990). It has been originally designed to be used with high school and college students, where they rewrite or retell another person's thoughts. The originality of expression rather than originality of thought is the focal in this technique (Anastasio, 2006, p. 1).

Texts are used as samples in many ways. They may be employed for transcribing, which involves reading a passage of prose and copying it on a paper. They can be for translation. It requires a complete mastering of the original thoughts, writing the thoughts down in the target language, and revising the version with a view to bring them into close conformity with the thoughts of the original (Anastasio, 2006, p.4). Reproduction or paraphrasing is another form of 
using sample texts. It includes rewriting a passage in other words to make its meaning clear. Moreover, we may use long passages of prose or poetry to produce a concise and lucid summary. This is called condensation. In this context, it must be said that any kind of background sources use is a highly complex process. It involves reading, understanding, learning, relating, planning, writing, revising, editing, and orchestrating (Campbell, 1990). As far as this project is concerned, the reading assignments will not be designed to brush up the quotation, paraphrasing, or summarizing skills. Rather, they will serve as samples to aid students compose effective five paragraph argumentative essays.

Therefore, the way the Background Reading Text Technique is practiced is by no means a reflection of the classroom context requirements. The composition writers' levels and the instruction purposes are the central variables that dictate the nature of the practice. Without reservation, the reading-writing connection is of an invaluable effect on learners' language acquisition. This requires that language teachers and learners should be aware of the fruits of this collaboration.

I.4.2. Reading-writing correlation with regard to learners' achievements. Among the wide range of issues scholars are interested in tackling is the effect of reading-writing connections on students' learning (Flihan, 2006, p.5). In particular, they have begun to scrutinise the relationship between reading and writing processes in actual practice. They have also examined the ways in which reading can support writing skills. Furthermore, they have studied the classroom atmospheres and the instructional activities indispensable in fostering the academic writers' competence. In the following, we will touch on the two first concepts; whereas, the last issue will be discussed later on.

Squire (1983) points out that when reading and writing are taught as two related composing processes, they influence and prompt the development of reading, writing, and thinking. In their turn, Graves \& Hanson (1983) affirm that learners use the texts to reflect on their knowledge and experiences, then, to generate and synthesis ideas for writing. It is due to this reflection that they will develop a sense of authorship necessary for the composing processes.

The transfer and the sharing of knowledge and techniques are also illustrated in various inquiries. In his book Teaching Writing Skills, Byrne (1988) asserts that texts as models for practice are frameworks within which the rhetorical devices- logical, grammatical, and lexical - can be taught. Learners borrow literary techniques as imagery and repetition from sample texts to produce better compositions (Comstock, 1992). Additionally, the introduction to a variety of challenging texts will help the learners to recognize the techniques of structuring the different genres, which will impact their writing skills (Reading and Writing Connection, 2006). As a logical consequence, reading may be conceived as "a necessary precondition for any writing task, since the writer must be aware of the structure of a particular type of writing before he can produce it" (Bolitho \& Kennedy, 1985, p.85; in Escribano, 1999, p. 58).

In short, writing is basically a matter of communicating meaning. The introduction of reading to writing classrooms has been proved to be a critical factor in enhancing the quality of the messages the academic writers produce when composing. Thus, it promotes learners' 
achievements in acquiring a second language. In this concern, it must be said that a careful selection of the instructional strategies is paramount for successful reading-writing connections.

I.4.3. Reading-writing instructional strategies. Many teachers, even the more experienced ones, face difficulties in designing the appropriate strategies to teach writing. Absolutely, this will be more difficult when we speak about an integration between the two skills reading and writing in the hope that we will evolve the composing abilities of our learners. Nowadays, the investigations attempt to provide answers on the questions how, when and where reading-writing strategies are used, by whom and for what purposes (Flihan, 2006, p. 3).

To set the stage, the prior factor towards a wise selection of a reading-writing instructional strategy is the belief that reading empowers writing (Reading and Writing Connections, 2006). Both skills are interdependent processes essential to each other and mutually beneficial (Holt \& Vacer, 1984). Therefore, they should be taught naturally in everyday situations (Wilson, 1981). In this vein, teachers should help the learners to extend a need for communication. Consequently, they will read with the sense of a writer and write with the sense of a reader (Reading and Writing Connections, 2006).

After, the instructors should offer opportunities to their learners to construct meaning from texts. For this aim, learners should learn to focus on texts in more depth and detail with ample time for rereading (Ibid). They should examine the purpose of a piece of writing, how the writer has established contact with the reader, how he has organized his material through the use of certain logical and grammatical material (Byrne, 1988, p. 14). Besides, they need to learn how to build knowledge about the forms and the functions of the language (Goodman \& Goodman, 1983; Mayo, 2000).

Then, learners should experience a variety of written works. Effective reading-writing instructional strategy should cover different topics, styles, and genres (Reading and Writing Connections, 2006). Learners have to learn not only how to write correctly, but also how to define, to classify, to describe, and to make modifications (Davies \& Widdowson; in Allen \& Corder, 1974, p.181). Scholarships indicate that essay writing is an efficient tool to transfer the acquired knowledge on styles and genres into a concrete written form (Flihan, 2006, p. 8). This type of activity provides time for students to think most flexibly as they develop their ideas (Langer \& Applebee, 1987, p. 100). It should incorporate four main stages: planning, drafting, revising, and editing.

Another sensitive variable when designing a reading-writing strategy is the topic on which learners will compose. Learners show a difference in the quality of their written productions across the various topics (TESL-EJ, 2006, p. 2). Hoetker (1982) cites two examinations conducted by White between 1973 and 1974 . The results of the former have been better as it has relied on learners' personal experience. However, the latter has been more cognitively demanding, which has engendered lower scores. In 1984, O'Donnell has confirmed that there are three types of subjects that lead to less effective compositions: difficult, uninteresting, or inappropriate. Also, some researchers have argued that the less options on the topics to be composed, the better learners' performance is (Hoetker, 1982). 
Summing up, a strategic instruction in a second language writing classroom has four idiosyncratic features. It approaches reading and writing as two complementary composing processes. It teaches learners to read critically and to construct meaning by scrutinising the structure and the content of a piece of writing. It exposes learners to numerous text samples of various forms and functions. Essay writing practices are generally emphasized to enable learners apply what they have theoretically learnt. Finally, the topics to be developed are carefully selected to match learners' cognitive abilities and interests.

\section{The Experimental Manipulation \\ II.1. A blue print of the study}

This study is originally constructed to examine the role of the Background Reading Text Technique in developing foreign language learners' writing proficiency. In the preceding section, we have shed light on some of the positive effects of this technique relying on scholarships conducted by other researchers. Yet as we will see, we have made certain modifications on the way of introducing and applying the Background Reading Text Technique in writing classes. Naturally, new variables will emerge which requires a current experimental study.

We think that the empirical investigation is of high value for the accomplishment of our work. It enables us to explore how and to what extent our learners are influenced by the incorporation of reading assignments in composition instruction. In addition, the amassed data is paramount to test the validity of our hypothesis, therefore, the efficacy of the Background Reading Text Technique.

In this light, this section depicts all the building block steps to construct the body of our research project. Afterward, we will launch our experiment accompanied by an analysis at each stage. To close the section, we will discuss and draw conclusions from the obtained results according to our objectives and hypothesis.

II.1.1. Source of interest and motivation. Our source of interest and motivation for selecting this research problem originate from two exciting reasons. In the first place, as members of the English department staff at the University of Bejaia and teachers of written expression, it is our desire and concern to improve learners' writing skills. In the second place, the choice of argumentative essays rather than any other type of essays is due to the fact that the chief problem the second year students of English suffer from is in argumentation which is found not only in the academic contexts, but also in learners' mundane activities. Convincing others is an art that requires a special use of language forms and content, and fluency in the ideas, in particular, in formal contexts, which is not an easy task to be accomplished, particularly in a written form and for academic purposes.

II.1.2. Aims and significance of the study. a- Aims: The objectives behind conducting the present inquiry are:

-To penetrate the multiple facets of the writing skill through a discussion of the distinct groundbreaking insights, approaches, and findings in this field.

-To explore the levels of deficiency in learners' argumentative compositions.

-To promote learners' competence in argumentation by carrying out the Background Reading Text Technique as a remedial solution during the instructional stage.

WwW.EUROKD.COM Doi: 
- As a broad intent, to provide the English department staff with a more practical technique to teach the argumentative essays at the university level.

b- Significance: We believe that the importance of our project lies on the fact that:

-It treats a major problem in language learning, that is, deficiency in writing skills and it tries to provide a remedial solution through the implementation of the Background Reading Text Technique.

- It involves a kind of innovation at the levels of:

- The criteria and the conditions under which the technique is conducted.

- The specific sample, time, and place of the investigation.

- It expands the writing staff knowledge of the relationship between the two skills reading and writing and the reciprocal effect between them.

II.1.3. Statement of the problem. Certainly, each research wok starts with queries about a given phenomenon that interests the researcher and inspires questions in his mind. Our cautious observations and piloting questionnaires to the second year LMD students of English at the University of Bejaia have permitted us to diagnose the major problem this subset of learners encounter during writing classes. They are unable to create argumentative written pieces that demonstrate mastery of composition skills. In an attempt to obviate this problem, we have proposed the implementation of the Background Reading Text Technique. Consequently, the core issue of the present inquiry is how teachers can develop their learners' composition skills in argumentative essays using the Background Reading Text Technique.

II.1.4. Research questions. a-Can reading during written expression classes be an effective contributory strategy in the acquisition and development of composition skills? If yes, what are the conditions under which the reading technique should be conducted to attain efficiency?

b-What is the level (s) at which the Background Reading Text Technique strongly contributes to learners' writing proficiency: the content and the outline structure, the organisation of ideas, or the use of the lexicon necessary to the function of argumentation?

c- Are the results obtained sufficiently seductive to adopt the Background Reading Text Technique in our classrooms?

II.1.5. Hypothesis. To solve the central problem and to answer the sub-problems, we have speculated a given solution embedded in the following hypothesis: "If the learners compose by means of analysing previously reading assignments, they may be able to plan more effectively and write better argumentative essays".

II.1.6. Population and sample. The participants we have chosen to undergo the experimental manipulation are the second year LMD English students who represent a population of two hundred ( $N=200)$ students, specifically the groups (9) and (10) at the university of AbderrahmaneMira of Bejaia. The platform of our choice is that essays writing are a part of the second year LMD students' syllabus in written expression credit.

For the sample, we have opted to the case study approach. The number of the participants is forty $(\mathrm{N}=40)$. They have been randomly selected without being aware that they are the applicants of our research work. Twenty $(\mathrm{N}=20)$ of them form group (9) which has undergone the experiment 
as they constitute the experimental subset. Paradoxically, the remainder twenty $(\mathrm{N}=20)$ learners consisting group (10) have received no experimental manipulation since they denote the control subset. Indeed, the case study approach helps us to trace in detail the evolution of writing skills in each individual language acquirer.

II.1.7. Method. Because the experimental manipulation is the research chief tool to collect data, we have employed an experimental method, using an analytic, quantitative approach.

II.1.8. Materials. - Two sample texts: the first is a "no I do not agree" argumentative text. The second is a "half agreement" argumentative text.

- Two analyses: one of the first sample text and the other of the second sample text.

- Six $(\mathrm{N}=6)$ suggested composition topics. At each stage of the experiment - diagnostic test, tests, and post-test - we have designed a "Yes/ No" argumentative essay and a "halfagreement" argumentative essay.

II.1.9. Procedures for Collecting and Treating Data. The procedures we have followed to amass credible and reliable data are the following:

a- The instructor has designed a diagnostic test for both groups (the experimental and the control) to check their profiles in writing argumentative essays. It has consisted of composing a five paragraph argumentative essay about two proposed topics. Each topic requires one of the two ways of developing an argumentative essay (Yes/No argumentative essays and half agreement argumentative essays).

b- Each group has been divided into two sub- groups comprising ten $(\mathrm{N}=10)$ students. Each sub- group has composed on one of the suggested topics. However, the profile of each group encompasses the profile of its two sub-groups.

c- The diagnostic test and all the latter compositions have been graded according to three main criteria: the content and the outline structure, the organisation, and the vocabulary.

d- After fifteen (15) days, the experiment has been launched. The instructor has given a reading assignment as homework for the experimental group. The sample text is a "no I do not agree" argumentative essay. It consists of five (5) paragraphs with about 350 words. The learners have to identify :

- The text function.

-The outline structure of the essay: The introductory paragraph (InP), the supporting paragraphs (SPs), the concluding paragraph (CP). : summary sentence (SumS), restatement of the thesis statement, final judgement (objective, subjective, objective/subjective).

-The hook if any.

- The thesis statement (THS).

-The function of each paragraph and its topic sentence and/or controlling idea.

-The supporting explanatory sentences (SESs), the supporting explanatory illustrative sentences (SEISs), the details (D), and the concluding sentence (if any) in each paragraph.

-The transitional words and expressions that determine the function of the sample text. 
e- In the classroom, the instructor and the learners have conferred on and adjusted the text analysis. The instructor has provided the students with additional transitional words and expressions.

f- Using the analysis of the sample text as a model, the learners have to compose a five paragraph argumentative essay on a suggested topic. This latter is of the same type with that of the reading assignment, that is, a "no I do not agree" argumentative essay.

g- The applicants are allowed to modify the structure and the content of each paragraph. In other words, the number and the nature (The hook, SESs and SEISs) of the sentences in each paragraph depend on learners' needs. Besides, they can make use of a variety of transitional words and expressions which they have been provided with during the course. The length of the essay is between 350-400 words. The participants have first to draught then to edit. The time allowed to finish the work is one hour.

h- Meanwhile, the control group has received an ordinary instruction. The teacher has explained the steps of writing "a no I do not agree" argumentative essay. He has also provided the learners with the transitional words and expressions which can be used. Besides, he has supplied them with a sample text. Thereafter, the subjects have been asked to compose an essay on the same suggested topic of the experimental subset, with the same length and time allocation.

i- Two weeks later, the same processes with both groups have been replicated. The sole difference is that the sample text for the experimental group and the instruction for the control subset are about a "half-agreement" argumentative essay. Therefore, the suggested topic on which both groups have composed is a half-agreement argumentative essay.

j- To ensure the credibility of the experimental manipulation results, a post test is designed for both groups. The steps at this stage are exactly the same with those of the diagnostic test.

k- Lastly, the results of the experimental group before, during, and after the application of the Background Reading Text Technique have been compared with those of the control group. In the next table, the three criteria on which the participants in both groups have been judged are presented.

\section{II.2. The diagnostic test}

Date: $02 / 10 / 2017$

$>$ Time: 13h: 00- 14h: $00 \mathrm{pm}$.

* Composition topic one: It is said that young people have to get their parents advice. According to you, what are the arguments of the opponents?

* Composition topic two: Some people think that doctors should tell their patients the whole truth about their disease; others reject this view. State the arguments of each group. 
Table 4. The three criteria of learners' compositions grading

\begin{tabular}{|c|c|c|c|}
\hline \multirow{2}{*}{$\begin{array}{c}\text { The } \\
\text { grading } \\
\text { levels }\end{array}$} & \multicolumn{3}{|c|}{ The compositions criteria } \\
\hline & Content and outline structure & Organisation & Vocabulary \\
\hline $\begin{array}{l}\text { Level } \\
\text { one }\end{array}$ & $\begin{array}{l}\text { - A five or less than a five paragraph } \\
\text { essay with poor planning. } \\
\text { - Little relevance to the topic. } \\
\text { - Poor development of the thesis } \\
\text { statement. } \\
\text { - Non substantive and poor mastery of } \\
\text { subject. }\end{array}$ & $\begin{array}{l}\text { - The controlling idea of each } \\
\text { paragraph is not clearly stated, with } \\
\text { confused and disconnected ideas. } \\
\text {-Loosely organised ideas. } \\
\text { - No cohesion. }\end{array}$ & $\begin{array}{l}\text {-The word / } \\
\text { expression choice } \\
\text { and usage is } \\
\text { inappropriate to } \\
\text { the essay function. }\end{array}$ \\
\hline $\begin{array}{l}\text { Level } \\
\text { two }\end{array}$ & $\begin{array}{l}\text {-A five or less than a five paragraph } \\
\text { essay with average planning. } \\
\text {-Less relevance to the topic. } \\
\text {-Limited development of the thesis } \\
\text { statement. } \\
\text {-Little substance and limited } \\
\text { knowledge of subject. }\end{array}$ & $\begin{array}{l}\text {-The controlling idea of each paragraph } \\
\text { is not clearly stated, with less } \\
\text { argumentation and support. } \\
\text {-Fewer organisations of the ideas. } \\
\text {-Somehow cohesive. }\end{array}$ & $\begin{array}{l}\text {-The word } \\
\text { /expression choice } \\
\text { and usage is less } \\
\text { appropriate to the } \\
\text { essay function. }\end{array}$ \\
\hline $\begin{array}{l}\text { Level } \\
\text { three }\end{array}$ & $\begin{array}{l}\text {-A five paragraph essay with good } \\
\text { planning. } \\
\text {-Mostly relevant to the topic. } \\
\text {-Well development of the thesis } \\
\text { statement. } \\
\text {-Adequate range of ideas and good } \\
\text { knowledge of subject. }\end{array}$ & $\begin{array}{l}\text {-The controlling idea of each paragraph } \\
\text { is clearly stated, with good } \\
\text { argumentation and support. } \\
\text {-Well organised ideas. } \\
\text {-Cohesive. }\end{array}$ & $\begin{array}{l}\text {-The word / } \\
\text { expression choice } \\
\text { and usage is } \\
\text { appropriate to the } \\
\text { essay function. }\end{array}$ \\
\hline $\begin{array}{l}\text { Level } \\
\text { four }\end{array}$ & $\begin{array}{l}\text {-A five paragraph essay with effective } \\
\text { planning. } \\
\text {-Through development of the thesis } \\
\text { statement. } \\
\text {-Substantive and high knowledge of } \\
\text { subject. }\end{array}$ & $\begin{array}{l}\text {-The controlling idea of each paragraph } \\
\text { is clearly stated, strongly and } \\
\text { substantially argued and supported. } \\
\text {-Fully organised ideas. } \\
\text {-Highly cohesive. }\end{array}$ & $\begin{array}{l}\text {-Effective word / } \\
\text { expression choice } \\
\text { and usage } \\
\text { appropriate to the } \\
\text { essay function }\end{array}$ \\
\hline
\end{tabular}

Inspired from Jacobs et al. (1981); cited in Weigle (2002)

\section{II.2.1. Learners' profiles in the diagnostic test}

Table 5. The experimental group profile

\begin{tabular}{|c|c|c|c|c|}
\hline \multirow{2}{*}{ The essay criteria } & \multicolumn{3}{|c|}{ The number and the percentage of students at each level } \\
\cline { 2 - 5 } & Level 1 & Level 2 & Level 3 & Level 4 \\
\hline Content and outline structure & $(0 \%)$ & $(60 \%)$ & $(40 \%)$ & $(0 \%)$ \\
\hline Organisation & $(60 \%)$ & $(40 \%)$ & $(0 \%)$ & $(0 \%)$ \\
\hline Vocabulary & $(80 \%)$ & $(20 \%)$ & $(0 \%)$ & $(0 \%)$ \\
\hline
\end{tabular}


Table 6. The control group profile

\begin{tabular}{|c|c|c|c|c|}
\hline \multirow{2}{*}{ The essay criteria } & \multicolumn{4}{|c|}{ The number and the percentage of students at each level } \\
\cline { 2 - 5 } & Level 1 & Level 2 & Level 3 & Level 4 \\
\hline Content and outline structure & $(10 \%)$ & $(60 \%)$ & $(30 \%)$ & $(0 \%)$ \\
\hline Organisation & $(30 \%)$ & $(50 \%)$ & $(20 \%)$ & $(0 \%)$ \\
\hline Vocabulary & $(30 \%)$ & $(60 \%)$ & $(10 \%)$ & $(0 \%)$ \\
\hline
\end{tabular}

\section{II.3. The experiment tests}

$>$ Part one: "No I do not agree" argumentative essays

$>$ Date: $16 / 10 / 2017$

$>$ The experimental group:

-Time: $13 \mathrm{~h}: 00 \rightarrow 14 \mathrm{~h}: 00 \mathrm{pm}$.

-Sample text one: Zoos

-Analysis of sample text one

$>$ The control group:

-Time: $14: 00 \rightarrow$ 15:00 pm.

-Ordinary instruction on "No I do not agree" argumentative essay.

* Composition topic one: Many educators assert that corporal punishment should be ceased in schools. State the opposing views.

\section{Sample Text One: Zoos}

Zoo animals are usually kept in very cramped enclosures and do not behave like their wild counterparts. Polar bears, for example, are given about 10 metres of walking space whereas in their Arctic home they roam for many hundreds of kilometres. Similarly, primates, big cats and birds are often confined in cages where they lack exercise and stimulation. Many animals develop unnatural habits such as pacing back and forth or swaying from side to side.

Supporters of zoos argue that they help to conserve endangered species, but in fact they are not very good at this. Even the world famous panda breeding programme has been very costly and unsuccessful. Also, zoo life does not prepare animals for the challenges of life in the wild. For example, two rare lynxes released into the wild in Colorado died from starvation even though the area was full of hares, which are a lynx's natural prey.

The zoo is an unnatural environment that exposes animals to numerous dangers. Diseases often spread between species that would never live together naturally. For example, many Asian elephants have died in US zoos after catching herpes from African elephants. Furthermore, zoo animals are often exposed to chemicals, solvents and other toxic substances. Finally, it is common for visitors to tease and provoke caged animals.

In conclusion, therefore, it is not true to say that zoos are educational or that they help to protect endangered species. In reality, they only teach us how wild animals behave when they are confined in small spaces. Breeding programmes provide zoos with good publicity, but in fact most of them are failures. Finally, zoo animals are probably more at risk of dying from disease or poisoning than their wild counterparts. It is time that we abolish these cruel institutions! 
Frankie Meehan (2007)

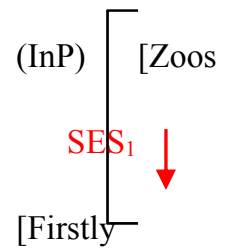

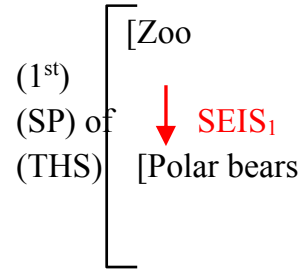

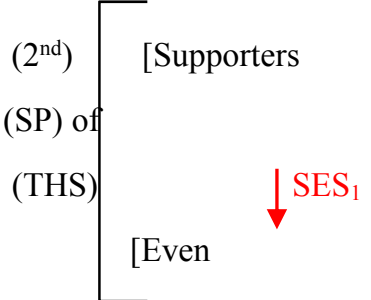

The Thesis Statement

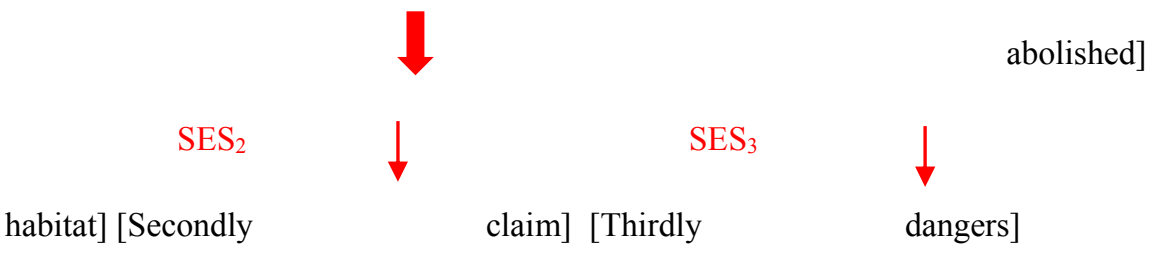

The First Topic Sentence / Controlling Idea

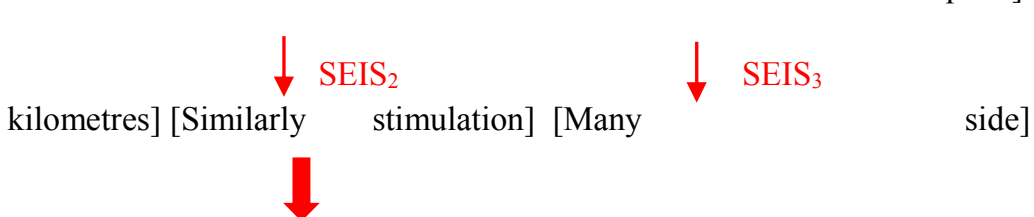

The Second Topic Sentence / Controlling Idea

at this]

$\mathrm{SES}_{2}$

unsuccessful] [Also

the wild ]

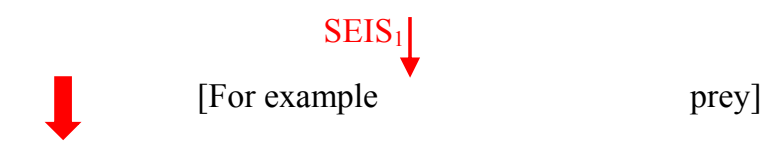

The Third Topic Sentence / Controlling Idea

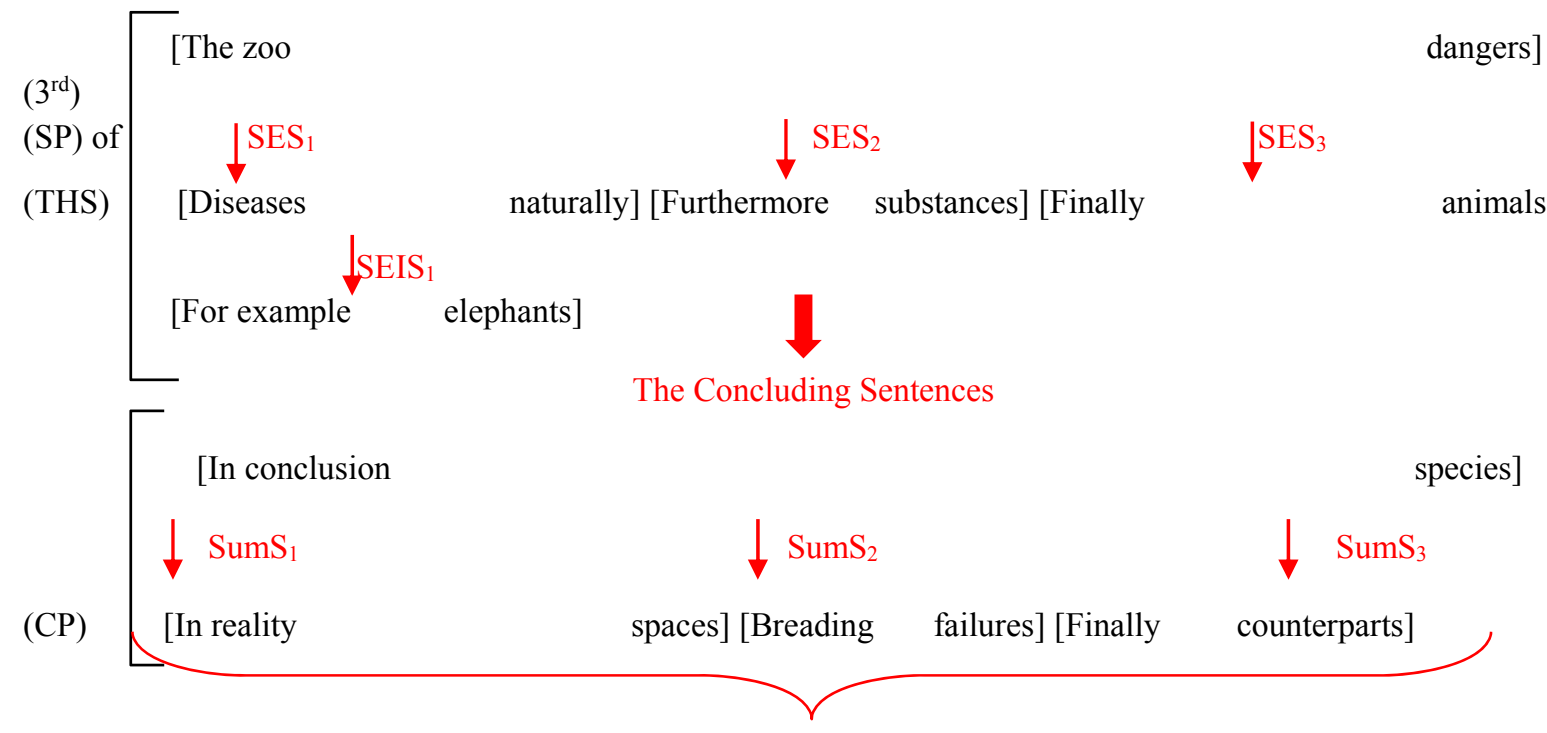

Restatement of the Thesis Statement [It is institutions]

Figure 3. Analysis of Sample Text One 
Table 7. The linking words in sample text one

\begin{tabular}{|l|l|l|}
\hline \multicolumn{1}{|c|}{ The linking words } & \multicolumn{1}{|c|}{ From the text } & \multicolumn{1}{c|}{ Outside the text } \\
\hline $\begin{array}{l}\text { 1) To order the } \\
\text { arguments }\end{array}$ & -Firstly, secondly, thirdly. & $\begin{array}{l}\text {-In the first place, in the second place, in the } \\
\text { third place, first of all, next, then, as a point of } \\
\text { entry, as a second point, the primarily point, the } \\
\text { following point. }\end{array}$ \\
\hline $\begin{array}{l}\text { 2) To introduce and } \\
\text { explicate the } \\
\text { arguments. }\end{array}$ & $\begin{array}{l}\text {-Nouns: supporters. } \\
\text {-Verbs: claim, argue. } \\
\text {-Transitional devices: therefore, for } \\
\text { example, similarly, even though, } \\
\text { also, furthermore, finally. }\end{array}$ & $\begin{array}{l}\text {-Nouns: opponents, adversaries, proponents, } \\
\text { supporters, advocates. } \\
\text {-Verbs: confirm, affirm, believe, think, agree, } \\
\text { disagree, assert, state, reject, defend. } \\
\text {-Transitional advices: } \\
\text { consequently, as a result, with this in mind, } \\
\text { moreover, in addition, then, next, for instance, } \\
\text { in particular, to demonstrate, to illustrate. }\end{array}$ \\
\hline 3) To conclude. & $\begin{array}{l}\text {-In conclusion, therefore, it is not } \\
\text { true, in reality, but in fact, finally, it } \\
\text { is time that. }\end{array}$ & $\begin{array}{l}\text {-Given these facts, hence, therefore, thus, in a } \\
\text { nutshell, briefly, overall, to sum up, summing } \\
\text { up. }\end{array}$ \\
\hline
\end{tabular}

\section{II.3.1. Learners' profiles in topic one}

Table 8 . The experimental group profile

\begin{tabular}{|c|c|c|c|c|}
\hline \multirow{2}{*}{ The essay criteria } & \multicolumn{3}{|c|}{ The number and the percentage of students at each level } \\
\cline { 2 - 5 } & Level 1 & Level 2 & Level 3 & Level 4 \\
\hline Content and outline structure & $(10 \%)$ & $(20 \%)$ & $(70 \%)$ & $(00 \%)$ \\
\hline Organisation & $(30 \%)$ & $(40 \%)$ & $(30 \%)$ & $(00 \%)$ \\
\hline Vocabulary & $(20 \%)$ & $(50 \%)$ & $(30 \%)$ & $(00 \%)$ \\
\hline
\end{tabular}

Table 9. The control group profile

\begin{tabular}{|c|c|c|c|c|}
\hline \multirow{2}{*}{ The essay criteria } & \multicolumn{3}{|c|}{ The number and the percentage of students at each level } \\
\cline { 2 - 5 } & Level 1 & Level 2 & Level 3 & Level 4 \\
\hline Content and outline structure & $(10 \%)$ & $(30 \%)$ & $(60 \%)$ & $(0 \%)$ \\
\hline Organisation & $(20 \%)$ & $(60 \%)$ & $(20 \%)$ & $(0 \%)$ \\
\hline Vocabulary & $(20 \%)$ & $(70 \%)$ & $(10 \%)$ & $(0 \%)$ \\
\hline
\end{tabular}

Part two: "Half agreement" argumentative essays

Date: $30 / 10 / 2017$

$>$ The experimental group:

-Time: $13 \mathrm{~h}: 00 \rightarrow$ 14h:00 pm.

-Sample text two: Telecommuting: will it change the world?

-Analysis of sample text two

$>$ The control group:

-Time: $14: 00 \rightarrow$ 15:00 pm. 


\title{
-Ordinary instruction on "Half agreement" argumentative essays.
}

\author{
* Composition topic two: Certain educational psychologists believe that boys and \\ girls should attend separate schools. The opponents think that this should not \\ be done. What do you think the arguments of each group?
}

\section{Sample Text Two: Telecommuting: Will It Change the World?}

Telecommuting will have major effects in the worlds of work and family life. On the contrary, its biggest effect will be in the area of individual freedom, responsibility, and time management. In what follows, we will discuss the arguments for and against telecommuting.

The advocates of telecommuting affirm that work and workplaces will alter dramatically. In the first place, offices may become smaller, as fewer desks are needed. In the second place, there will be greater need for high-bandwidth connections to link the office and the home, and even homes to other homes, as other employees and supervisors also begin working at home. In the third place, hours spent commuting, traffic jams, and fights for parking should diminish, as workers make fewer journeys or work staggered hours.

Moreover, family life will change. To begin with, workers, both husbands and wives, can arrange their work around family commitments such as taking children to school, cooking, leisure activities, etc. Then, households will also have to set aside areas for work - particularly if both spouses are telecommuting.

However, although the ideas of more time at home and less time traveling are attractive, there are some drawbacks to telecommuting. For one thing, people may feel unable to escape their work, and may even work longer or more unsocial hours. Next, the quality of work may suffer because of the reduced face-to-face interaction with other employees. There may be delays if other workers are not immediately available. Additionally, telecommuters may feel isolated or unmotivated, or insecure about decisions. Further, a major change will be in the way people think about work as a place or an institution. Moreover, workers may feel less loyal to a company and more inclined to change jobs or work part-time or on contract.

In a nutshell, the effects are difficult to predict because they depend on the extent to which telecommuting becomes popular. However, telecommuting could be the start of a major societal shift, possibly as big as the Industrial Revolution which created our present ideas of work. 


\section{Write Fix (2009)}

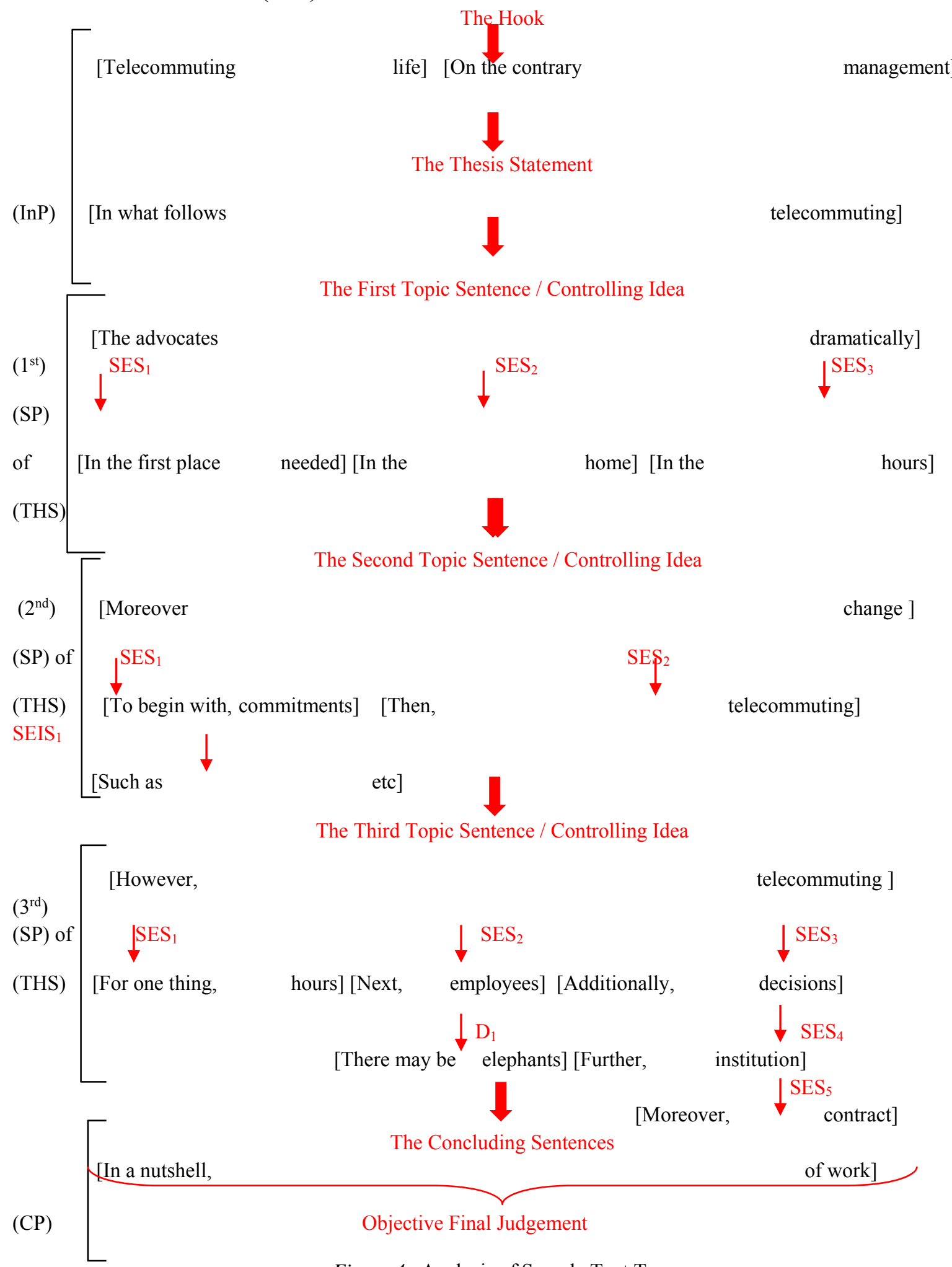

Figure 4. Analysis of Sample Text Two 
Table 8. The linking words in sample text two

\begin{tabular}{|l|l|l|}
\hline \multicolumn{1}{|c|}{ The linking } & \multicolumn{1}{|c|}{ From the text } & \multicolumn{1}{|c|}{ Outside the text } \\
words & $\begin{array}{l}\text {-In the first place, in the second place, } \\
\text { in the third place, to begin with, then, } \\
\text { 1) To order the as, for one thing, next, } \\
\text { arguments } \\
\text { additionally, further, moreover. }\end{array}$ & $\begin{array}{l}\text {-In the first place, in the second place, in the third } \\
\text { place, first of all, next, then, as a point of entry, } \\
\text { as acond point, the primarily point, the } \\
\text { following point. }\end{array}$ \\
\hline $\begin{array}{l}\text { 2) To introduce and } \\
\text { explicate } \\
\text { arguments. }\end{array}$ & $\begin{array}{l}\text {-Nouns: arguments, advocates, } \\
\text { drawbacks. } \\
\text {-Verbs: affirm. } \\
\text {-Transitional devices: on the contrary, } \\
\text { in what follows, for, against, } \\
\text { moreover, however. } \\
\text { supporters, advocates. } \\
\text {-Verbs: confirm, affirm, believe, think, agree, } \\
\text { disagree, assert, state, reject, defend. } \\
\text {-Transitional advices: } \\
\text { consequently, as a result, with this in mind, } \\
\text { moreover, in addition, then, next, for instance, in } \\
\text { particular, to demonstrate, to illustrate. }\end{array}$ \\
\hline 3) To conclude. & $\begin{array}{l}\text { - In a nutshell. } \\
\text { nutshell, briefly, overall, to sum up, summing up. }\end{array}$ \\
\hline
\end{tabular}

\section{II.3.2. Learners' profiles in topic two}

Table 9. The experimental group profile

\begin{tabular}{|c|c|c|c|c|}
\hline \multirow{2}{*}{ The essay criteria } & \multicolumn{3}{|c|}{ The number and the percentage of students at each level } \\
\cline { 2 - 4 } & Level 1 & Level 2 & Level 3 & Level 4 \\
\hline Content and outline structure & $(0 \%)$ & $(20 \%)$ & $(80 \%)$ & $(0 \%)$ \\
\hline Organisation & $(10 \%)$ & $(20 \%)$ & $(60 \%)$ & $(10 \%)$ \\
\hline Vocabulary & $(10 \%)$ & $(10 \%)$ & $(50 \%)$ & $(30 \%)$ \\
\hline
\end{tabular}

Table 10. The control group profile

\begin{tabular}{|c|c|c|c|c|}
\hline \multirow{2}{*}{ The essay criteria } & \multicolumn{4}{|c|}{ The number and the percentage of students at each level } \\
\cline { 2 - 5 } & Level 1 & Level 2 & Level 3 & Level 4 \\
\hline Content and outline structure & $(0 \%)$ & $(20 \%)$ & $(70 \%)$ & $(10 \%)$ \\
\hline Organisation & $(10 \%)$ & $(60 \%)$ & $(30 \%)$ & $(0 \%)$ \\
\hline Vocabulary & $(0 \%)$ & $(70 \%)$ & $(20 \%)$ & $(10 \%)$ \\
\hline
\end{tabular}

\section{II.4. The post -test}

Date: $13 / 11 / 2017$.

Time: $13 \mathrm{~h}: 00 \rightarrow$ 14h:00 pm.

* Composition topic one: It is said that wars are sometimes right and useful. State the No I do not agree arguments to the preceding view.

* Composition topic two: A hot debate is increasing these recent days about whether women should stay at home or they can go out to work. In a five paragraph essay give the evidence for each view. 


\section{II.4.1. Learners' profiles in the post - test}

Table 11. The experimental group profile

\begin{tabular}{|c|c|c|c|c|}
\hline \multirow{2}{*}{ The essay criteria } & \multicolumn{4}{|c|}{ The number and the percentage of students at each level } \\
\cline { 2 - 5 } & Level 1 & Level 2 & Level 3 & Level 4 \\
\hline Content and outline structure & $(10 \%)$ & $(10 \%)$ & $(80 \%)$ & $(0 \%)$ \\
\hline Organisation & $(0 \%)$ & $(30 \%)$ & $(40 \%)$ & $(30 \%)$ \\
\hline Vocabulary & $(0 \%)$ & $(20 \%)$ & $(20 \%)$ & $(60 \%)$ \\
\hline
\end{tabular}

Table 12. The control group profile

\begin{tabular}{|c|c|c|c|c|}
\hline \multirow{2}{*}{ The essay criteria } & \multicolumn{3}{|c|}{ The number and the percentage of students at each level } \\
\cline { 2 - 5 } & Level 1 & Level 2 & Level 3 & Level 4 \\
\hline Content and outline structure & $(0 \%)$ & $(30 \%)$ & $(60 \%)$ & $(10 \%)$ \\
\hline Organisation & $(10 \%)$ & $(60 \%)$ & $(20 \%)$ & $(10 \%)$ \\
\hline Vocabulary & $(0 \%)$ & $(50 \%)$ & $(30 \%)$ & $(20 \%)$ \\
\hline
\end{tabular}

\section{Discussion}

We have been engaged in a long, complex process of investigating the effects of the Background Reading Text Technique in developing foreign language learners' compositions in argumentative essays. The process we have preceded through has been launched with a diagnostic test, then an experimental manipulation, and finally a post test. The wealth of information we have obtained, their implications, and their results are the essence of the current discussion.

To set the stage, the diagnostic test has provided us with a useful framework of the subjects' profiles in composing five paragraph argumentative essays. Although the results of the experimental and control groups demonstrate a deficiency in composing the essays, the control group has shown better performance than the experimental one. The skills of establishing and organising the ideas, and using the appropriate lexicon have been the major gap in learners' compositions. The content and outline structure, however, has not been a real problematic factor for both groups. This maybe because the selected topics are available for all learners and the structure of a five paragraph essay is a prevalent knowledge. These results are diagnostic symptoms of learners 'deficiency in composing five paragraph argumentative essays. This implies a need for a remedial solution to help learners overcome their deficiency and to transcend their primary levels. Consequently, the prior findings have been an incentive for us to check the effectiveness of implementing the Background Reading Text Technique in writing classes as an instructional technique.

Subsequently, we have introduced our technique to the experimental group. The first topic of the experimental manipulation has initiated the hints of change. In comparison to the control group, the experimental subset has made a remarkable progress, specifically in the organisation and vocabulary criteria. It is a positive indication of the efficacy of using a sample text analysis to teach argumentative essays. Simultaneously, the instructional method the control group has undergone seems to be less effective. Indeed, the analysis of texts as models provides the learners 
with the opportunity to scrutinises each paragraph structure and content. Learners have to identify how the writer has stated his thesis statement, his controlling ideas and separated them from the other elements of the paragraph. Furthermore, they learn how to organise their thoughts in a cohesive and coherent manner with the use of the necessary transitional words and expressions.

Certainly, there is a large difference between teaching theory and turning it into practice. When the subjects are immersed in a deep analysis of a text, they are supplied with concrete models of language use, in a particular context, and for a specific functional purpose. These texts serve as prototypes instrumental for the learners in the early stages of developing their compositions. Of course, the imitation of the prototypes is not so automatic. The participants analyse the author's text and follow the basic elements which have been discussed before. Meanwhile, they are given the freedom to make certain modifications limited by the instructor. Accordingly, a kind of creativity is encouraged but under the teacher's guidance. The little development both groups have achieved in the content and outline structure criterion may be related to the decrease of learners' anxiety comparing to the diagnostic test.

Thereafter, the subjects have been asked to compose on the second topic which is of the halfagreement type. The collected data have shown further advance from both parts, the experimental and the control groups. Some learners have even reached level four in the two critical criteria: organisation and vocabulary. Again, the experimental subset performance has been more skilful than that of the control group. It is another additional point in the account of the Background Reading Text Technique. In a steady, sequential process, the analysis of sample texts has contributed to learners' abilities of organising the ideas and using the lexicon that determines the function of a half-agreement essay. This does not mean to neglect the value of the instructional method used with the control group as this subset has also made a progress. In this context, we should refer to the role of the frequent practice in promoting the individual language acquirer achievements. Our subjects in both groups have composed three times which might be a secondary contributory factor in learners' improvement. Moreover, the criterion of content and outline structure enrols gradual development with approximately equal results in either subsets. Hence, the emphasis is made on the nature of the subject matter of the composition which matches most of the participants' cognitive abilities and schemata.

Lastly, the participants of the experimental and control groups have taken a post-test. The former has immensely promoted the criterion of organisation and vocabulary use; the latter has slightly evolved the criterion of vocabulary. It is obvious that when the learners analyse sample texts by themselves then build new essays following the analysis, they will possess better permanent writing skills. Always, the results obtained in the criterion of content and outline structure by both subsets are close to each other. It is a cogent evidence that the suggested topics and the outline of the five paragraph argumentative essays do not present real issues for our subjects.

Briefly, the correlation between reading and writing skills during composition classes has proved effectiveness. The results of our study support those of earlier investigations which we have discussed in chapter two. The examination of samples of argumentative texts has served as 
tangible models paramount to perceive the ways of constructing, organising, and using vocabulary from real language use contexts. During and after the experimental manipulation, the Background Reading Text Technique has been an effective contributory strategy in the acquisition and development of learners' composition skills. It has significantly aided the experimental subset members to brush up their skills in the two criteria: firstly, the vocabulary, and secondly the organisation of ideas. In this vein, our hypothesis which states that: "If the second year LMD English students compose by means of analysing previously reading assignments, they will be able to plan more effectively and write better argumentative essays" is validated.

\section{Implications and Suggestions}

Although the improvements in the technique we have introduced have induced meaningful development of learners' argumentative composition skills, there are some potentially important implications for (FL) writing instruction based on existing findings.

Foreign language writing teachers need ample time to train their learners on argumentative essays. Hence, they will have more opportunities to practise on numerous models of argumentation. This will prompt a high control over their composing skills. One should add here that immediate composition tasks after each session are paramount. They provoke multiple metacognitive strategies (Oxford, 1990). (FL) writing teachers have also to weave the simple suggested texts into more complex ones, with a profound examination of every model. In such a way, the teachers will assist learners in identifying how the different writers have used the language devices to convey particular messages through the medium of writing. (Byrne, 1988, p.9).

To create motivation, (FL) writing teachers are required to select sample texts and composition topics that match the schemata, the interests, and the needs of their learners. Naturally, this will engender effective productions (O'Donnell, 1984, p.4). Since they are in their early stages of composing argumentative essays, they need to imitate models of more professional writers. Yet, it is important for (FL) composition instructors to guide their learners to the aspects of imitation and to encourage a kind of expressivity and creativity. Moreover, the instructors should acquaint the learners with the main sequences of composing, with a special attention to the drafting stage as many learners tend to omit it.

\section{Conclusion}

The primary subject of this project is the empirical investigation to check the validity of our hypothesis. On the first place, we have set the aims and described in details the variables and the elements that build the experiment body. Moreover, we have established the three criteria on which learners' compositions are judged: the content and outline structure, organisation, and vocabulary. On the second place, we have launched the diagnostic test, the experimental manipulation, and the post test. We have collected data about the experimental and the control groups, then, we have compared between their results using tables. On the third place, we have discussed the results obtained by each group. The conclusions we have drawn confirm the fact that the Background Reading Text Technique plays a major role in promoting foreign language learners' argumentative essays. Furthermore, the obtained results are sufficiently seductive to adopt this technique in our 
classrooms. Thus, we have validated our hypothesis, and we have answered the major problem and the sub-questions asked at the beginning of this study. With this in mind, a natural question arises on the surface to be the essence of further investigations, which articulates: Can the Background Reading Text Technique be equally effective to teach the other types of essays as it is with the argumentative compositions?

\section{References}

Abu Rasse, R. (2006). The new teacher induction programme in Bedouin schools in the Negev, Israel. Journal of Education for teaching, 36 (1), 35-55, 2010.

Allan, K.K. and Miller, S.M. (2001). Literacy and learning. U.S.A: Houghton Mifflin Company.

Anastasio, C. (2006). Writing through reading. Yale-New Haven Teachers Institute. Retrieved October, 7, 2017, from http:// www.yale.edu/ynhti/curriculum/units/1979/4/79.04.01.x.htm

Aulls, M.W. (1985). Education and power. Boston: Routledge and Kegan Paul.

Belanger, J. (1987). Theory and research into reading and writing connections: A critical review. Reading- CanadaLecture, 5, 10-18.

Bolitho \& Kennedy. (1985). In Escribano, D.P. (1999). Teaching writing through reading: A text- centered approach (p. 85). Madrid: Universidad Politecnica de Madrid.

Brown, H.D. (1994). Teaching by principles: An interactive approach to language pedagogy. Englewood Cliffs, NJ: Prentice Hall Regents.

Byrne, D.(1988). Teaching writing skills. London \& New York: Longman Group U.K. Limited.

Campbell, C. (1990). Writing with others' words: using background reading text in academic compositions. Cambridge: Cambridge University Press.

Carrel, P.L., \& Eisterhold, J.C. (1983). Schema theory and ESL reading pedagogy. TESOL Quarterly, 17, 553-573.

Comstock, M. (1992). Poetry and process: The reading/ writing connection. Language Arts, 69(4), 261-267.

Davies, A., \& Widdowson, H.G. In J.P.B., Allenand S.P.T., Corder. eds. (1974). Techniques in applied linguistics (pp.155-182). Oxford: Oxford University Press.

Eckhoff, B. (1983). How reading affects children's writing. Language Arts, 60, 607-616.

Escribano, D.P. (1999). Teaching writing through reading: A text- centered approach. Madrid: Universidad Politecnica de Madrid.

Ewer, J.R., \& Latorre, G. (1969). A course in basic scientific English. Londres: Longman.

Flihan, S. (2006). Writing and reading relationships: Constructive tasks. Center on English Learning Achievement. Retrieved October 7, 2017, from http://www.cela.albany.edu/publication/article/writeread.htm

Flowers, L.S., \& Hayes, J.R. (1980). The cognition of discovery: Defining a rhetorical problem. College Composition and Communication, 31, (1), 21-32.

Fries, C. (1945). Teaching and learning English as a second language. Ana Arbor: University of Michigan Press.

Goodman, K., \& Goodman, Y. (1983). Reading and writing relationships: Pragmatic functions. Language Arts, 60 (5), 590-599.

Grabe, W., \& Kaplan, R.B. (1989). Writing in a second language: Contrastive rhetoric. In D.M. Jonson \& D.H. Roen. eds. Richness in writing (pp.263-284). New York \& London: Longman.

Grabe, W., \& Kaplan, B. (1996). Theory and practice of writing: An applied linguistic perspective. London: Addition Wesley Longman Limited.

Graves, D., \& Hansen, J. (1983). The author's chair. Language Arts, 60 (2), 176-183. 
Gregg, L.W., \& Steinberg, E.R. eds. (1980). Cognitive processes in writing. Hillsdale, NJ: Earlbaum.

Hamp-Lyons, L., \& Roll, B. (1997). TOEFL 2000-writing: Composition communicating, and assessment (TOEFL Monograph Series Report $N^{\circ}$ 5). Princeton, NJ: Educational Testing Service.

Hairston, M. (1982). Windes of change: Thomas Kuhn and the revolution in the teaching of writing. College Composition and Communication, 33, 76-88.

Hayes, J.R. (1996). A new framework for understanding cognition and affect in writing. In C. M. Levy \& S. Ransdel (eds). The science of writing. NJ: Lawrence Earlbaum Associates.

Hierbert, E.H., Englert, C. S., \& Brennan, S. (1983). Awareness of text structure in recognition and production of expository discourse. Journal of Reading Behavior, 15, 63-79.

Hinds, J. (1987). Reader writer responsibility: A new typology. In U. Connor and R. Kaplan (Eds). Writing across languages: Analysis of second language text. Reading, MA: Addison-Wesley.

Hoetker, J. (1982). Effects of essay topics on student writing: A review of the literature. ERIC/ ED, 217-486 (-15-).

Holt, S.L., \& Vacer, J.L. (1984). Reading with a sense of writer: Writing with a sense of reader. In J.M. Jensen (ed). Comprehending and comprehension (pp.177-181). Urbana, IL: National Council of Teachers of English.

Horowitz, D. (1986a). Process not product: Less than meets the eye. TESOL Quarterly, 20, 141-144.

Hyland, K., \& Hamp-Lyons, L. (2002). EAP: Issues and directions. Journal of English for Academic Purposes, 1 (1) $1-12$.

Jacobs, H., Zinkgraf, S., Wormuth, D., Hartfiel, V., \& Hughey, J. (1981). Testing ESL Composition: A practical approach. Newbury House: Rowley, MA.

Kaplan, R.B. (1966). Cultural thought patterns in intercultural education. Language Learning, 16, 1-20.

Kaplan, R.B. (1967). Contrastive rhetoric and the teaching of composition. TESOL Quarterly, 1, 10-16.

Kroll, B. (1990). Second language writing: Research insights for the classroom. Cambridge: Cambridge University Press.

Kucer, S.B. (1987). The cognitive base of reading and writing. In J. Squire (ed). The dynamics of language learning (pp.27-51). Urbana: National conference in Research in English.

Langer, G.G., \& Applebee, A.N. (1987). How writing shapes thinking: A study of teaching and learning. Urbana IL: National Council of Teachers of English.

Leki, I. (1992). Understanding ESL writers. NH: Heinemann Educational.

Lina, B. (2007). Teaching the writing skill through the process approach to small groups. M.A. thesis, Batna: Batna University.

Mayo, L. (2000). Marking the connection: Reading and writing together. English Journal, 89 (4), 74-77.

Nelson, N. (1998). Language and writing. Publisher: International Thomson Publishing.

O’ Donell, H. (1984). ERIC/RCS Report: The effect of topic on writing performance. English Education, 16, 243249.

Ostler, S. (1987). English in parallels: Comparison of English and Arabic prose. In U. Connor \& K. Kaplan (eds). Writing across languages: Analysis of L2 language text. Reading, MA: Addition Wesley.

Oxford, R.L. (1990). Language Learning Strategies: What every teacher should know. New York: Newbury House/ Harper \& Row.

Perl, S. (1979). The composing process of unskilled college writers. Research in the Teaching of English, 13(4), 317336.

Raimes, A. (1983a). English as a second language: Remedies for composition teachers. In A. Freedman, I. Pringle, \& J. Yalden (eds). Learning to write: First language/second language (pp.258-272). London: Longman. 
Raimes, A. (1985). What unskilled ESL students do as they write: A classroom study of composing. TESOL Quarterly, 19 (2), 229-258.

Reading and Writing Connections. (2006). Conclusion. RWC. Retrieved October 9, 2017, fromhttp:/www.bridgew.edu/Library/CAGS_Projects/LTHMSON/web\%20page/rw\%20connection.html.

Reid, J. (1984a). The radical outliner and the radical brainstormer: A perspective on composing processes. TESOL Quarterly, 18, 529-533.

Reid, A. (1984b). Comments on Vivian Zamel's “The composing process of advanced ESL students: Six case studies”. TESOL Quarterly, 18,149-159.

Riley, J., \& Reidy, D. (2000). Developing writing for different purposes: Teaching about genre in the early years. London: PCP.

Rivers, W. (1968). Teaching foreign language skills. Chicago: University of Chicago Press.

Selinker, L., \& Trimble, L. (1976). Scientific and technical writing: Choice of tense. Forum, 14,4. Washington D.C.

Shanahan, T. (1984). Nature of the reading-writing relation: An exploratory multivariate analysis. Journal of Educational Psychology, 76, 466-477.

Shanahan, T., \& Lomax, R.G. (1986). An analysis and comparison of theoretical models of the reading-writing relationship. Journal of Educational Psychology, 78, 116-123.

Shanklin, N.K.L. (1982). Relating reading and writing: Developing a transactional theory of the writing process. Bloomington: Indian University School of Education.

Shih, M. ( 1986). Content-based approaches to teaching academic writing. TESOL Quarterly, 20, 617-648.

Silvia, T. In B. Kroll (ed). (1990). Second language writing: Insights for the language classroom (pp.11-20). Cambridge: Cambridge University Press.

SIL International.(1999). Writing skill. SILI. Retrieved November 13, 2017, from http://www.sil.org/lingualinks/LANGUAGELEARNING/Other Resources/Gudins FrALnggAndCltrLrnng Prgrm/WritingSkill.html-6K-

Sommers, N. (1980). Revision strategies of student writers and experienced adult writers. College Composition and Communication, 31, 378-388.

Squire, J (1983). The dynamics of language learning. Urbana: National conference in Research in English.

Stotsky, S. (1983). Research on reading/ writing relationships: A synthesis and suggested directions. Language Arts, 60, 627-642.

Swales, J. (1971). Writing Scientific English. London: Nelson.

Swales, J. (1990). Research genres: Explorations and applications. Cambridge: Cambridge University Press.

Taylor, B.(1978). Content and written form: A two-way street. TESOL Quarterly, 15, 5-13.

Taylor, B., \& Beach, R.W. (1984). The effects of text structure instruction on middle-grade students' comprehension and production of expository text. Reading Research Quarterly, 19, 134-146.

Teaching English as a Second Language. (2006). The role of topic and the reading/writing connection. TESL-EJ. Retrieved November 13, 2017, from https:/www. C:/Document and Settings/Administrateur/Mes documents/TheRole of Topic and the Reading/Writing Connection.

Tierney, R.J. (1992). Ongoing research and new directions. In J. Irwin \& M. Doyle (eds). Reading/writing connections: Learning from research ( pp. 246-260). Newark, DE: International Reading Association.

Uusen, A. (2006). Writing skills of $1^{\text {st }}$ and $2^{\text {nd }}$ stage students. Estonia: Tallin University Press.

Weigle, S.C. (2002). Assessing writing. Cambridge: Cambridge University Press.

Wilson, M. (1981). A review of recent research on the integration of reading and writing. The Reading Teacher,34 (8), 896-901. 
Yorkey, R. (1977). Practical EFL techniques for teaching Arabic-speaking students. In J. Alatis \& R. Crymes (eds). The human factors in ESL. Washington: TESOL.

Zamel, V. (1982). Writing: The process of discovering meaning. TESOL Quarterly,16, 195-209.

Zamel,V. (1983a). The composing processes of advanced ESL students: Six case studies. TESOL Quarterly, 17, 165187.

Zamel, V. (1987). Recent research on writing pedagogy. TESOL Quarterly, 21, 697-715. 